- 保护论坛・

\title{
三个“哪些”：植物园的使命
}

\author{
洪德 元 ${ }^{*}$ \\ (中国科学院植物研究所系统与进化植物学国家重点实验室, 北京 100093)
}

\section{Three "What": mission of a botanic garden}

\author{
Deyuan Hong* \\ State Key Laboratory of Systematic and Evolutionary Botany, Institute of Botany, Chinese Academy of Sciences, Beijing \\ 100093
}

2016年5月16日上海辰山植物园学术委员会举行年会，审议该园执行主任胡永红的“关于辰山植物园 十三五规划”的报告。委员们讨论热烈，充分肯定了永红的报告，并提出许多建设性的建议。会议剩下的 时间不多，作为学术委员会主任的我，只好用三五分钟发言。我说: 各位委员对永红报告的肯定和建议我 很同意。一个植物园当然应有美丽的园林, 百花齐放的美景, 使人流连忘返, 并在欣赏美景的同时丰富自 己的植物科学知识。但从长远来看, 一个植物园给人印象最深的是三个“哪些”。我用三个“哪些”阐述了我 对植物园使命的见解。令我意外的是, 黄宏文等委员赞许我的三个“哪些”。《生物多样性》主编马克平委 员当场邀我把这一简短发言发表于他所主编的刊物。兴奋之下，我欣然受命。下面的文字是对当时的即兴 发言略作修饰的结果, 供参考。

\section{1 引种收集了哪些}

如今, 人们有如此多的奇花异草, 美丽庭园, 植物园功不可没。我国植物异常丰富, 绚丽多彩, 被西方学者誉为“花园之母”。我国的植物园在搜集 中国本土植物方面做出了突出成绩, 相信将来会有 更大作为。因此, 我认为, 植物园的重要使命之一 是引种搜集植物资源, 特别是本土植物。既是出于 植物保护的目的，也是植物资源可持续利用不可或 缺的基础性工作。

\section{2 培育开发了哪些}

我指的不仅有花卉、林木，还有农作物、果蔬、 药用植物等等。我国是北半球植物最丰富的国家, 有取之不尽的资源。植物园已经并可继续为发展经 济、满足人类各方面需求发挥不可替代的作用, 这 也是植物园的重任和光荣的使命。

\section{3 挽救了哪些}

按《中国植物志》和Flora of China, 中国有维 管束植物(蕨类和种子植物) 31,000 多种，按我的估 计, 其中 15-20\%受威胁。以野生告丹(Paeonia)为例, 我们团队的研究表明, 9种野生牡丹全部为中国特 有, 其中大多数处于高度濒危状态。香港英文报纸 《南华早报》正确地解读了我们团队发表在英国皇 家学会会刊上关于栽培牡丹起源的文章，说: “----最喜爱的花卉，牡丹，要成孤儿了!”。胡永红团队正 在研究牡丹, 我希望他们承担起挽救候选国花“牡 丹’野生种的光荣使命, 不要让未来的国花真的成 为孤儿。

植物园的人才建设和研究项目的设立似应与 三个“哪些”相配合。

\footnotetext{
* 通讯作者 Author for correspondence. E-mail: hongdy@ibcas.ac.cn
} 